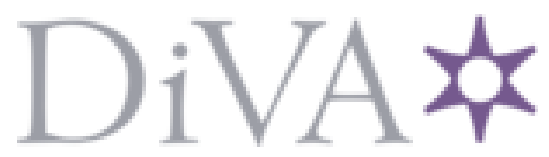

http://www.diva-portal.org

\title{
Preprint
}

This is the submitted version of a paper published in Convergence. The International Journal of Research into New Media Technologies.

Citation for the original published paper (version of record):

Neumayer, C., Svensson, J. (2014)

Activism and radical politics in the digital age: Towards a typology.

Convergence. The International Journal of Research into New Media Technologies

http://dx.doi.org/10.1177/1354856514553395

Access to the published version may require subscription.

N.B. When citing this work, cite the original published paper.

Permanent link to this version:

http://urn.kb.se/resolve?urn=urn:nbn:se:uu:diva-228642 


\title{
Activism and radical politics in the digital age
}

\section{Towards a typology}

\author{
Christina Neumayer \\ IT University of Copenhagen, Denmark
}

Jakob Svensson

Uppsala University, Sweden

\begin{abstract}
This article aims to develop a typology for evaluating different types of activism in the digital age, based on the ideal of radical democracy. Departing from this ideal, activism is approached in terms of processes of identification by establishing conflictual frontiers to outside Others as either adversaries or enemies. On the basis of these discussions, we outline a typology of four kinds of activists: the salon activist, the contentious activist, the law-abiding activist, and the Gandhian activist. The typology's first axis, between antagonism and agonism, is derived from normative discussions in radical democracy concerning developing frontiers. The second axis, about readiness to engage in civil disobedience, is derived from a review of studies of different forms of online activism. The article concludes by suggesting that the different forms of political engagement online have to be taken into account when studying how online activism can contribute to social change.
\end{abstract}

\section{Keywords}

Activism, civil disobedience, identity, radical democracy, social media. 


\section{Introduction}

In this article, we argue that notions of web-supported activism usually encompass many different types of participation, ranging from acts of civil disobedience - such as leaking information and hacking - to activities somewhat derogatorily labelled as slacktivism and clicktivism. The latter forms of participation could instead be regarded as expressions of political identity, similar to offline activities such as wearing a button or signing a petition. However, the boundaries between what might be regarded as acts of civil disobedience and identity expression online are blurred. This article develops a notion of activism that clarifies this blurring of boundaries by offering a typology of online activists, including components of identity negotiation as well as different forms of participation. This typology is developed from the perspective of radical democracy (Laclau and Mouffe, 1985; Mouffe, 2005). We have chosen to frame our typology within radical democracy because this perspective provides an understanding of activist participation as a) revolving around processes of identification, b) highlighting difference and dissent as inherently political, and c) important for widening the sphere of political participation beyond institutions of representative democracy.

In a digital democratic era, understood from late modern perspectives of reflexive individualisation and deliberative democracy, it has become common to lament activist participation as feel-good slacktivism (Morozov, 2011); as clicktivism (White, 2010); or as lacking collective, altruistic, and consensus-oriented components all together (Bauman, 2001). In contrast to such laments, we wish to stress the political and participatory aspects of activist identification and expression of difference and dissent. Activism broadens political participation beyond established power elites (Bennett and Amoshaun, 2009). Vital democracies should be able to cater to a multiplicity of voices. However, contemporary liberal representative democracies cannot include all political positions since majority decision-making always favours one position over another (Mouffe, 2005). Liberal democracies are influenced by the ideal of deliberation and communicative rationality (see Habermas, 1962), which radical democrats argue tends to overshadow differences and conflicts in general in a false air of agreements and consensus, tending to conceal relations of power as a result (Mouffe, 2005). From a radical democratic perspective, activism may thus ideally be understood as a coalition of excluded opinions, views, and expressions that no longer fit within the liberal parliamentary political arena and its quest for agreement and consensus. The digital realm plays an important role within a radical public sphere, allowing excluded and marginalised voices to be heard and bringing them into the political debate (Dahlberg, 2007). It is therefore important to study and understand different types of web-supported activism and whether they contribute to such a radical public sphere. 
The different forms that friend-enemy relations may take determine how activists contribute to the radical democratic ideal of a heterogeneity of subject positions, which is an important criterion for identifying as an activist. Another important criterion, we argue, is readiness to act in civil disobedience in general and in violent action and property damage in particular. Based on these dividing lines as well as with discussion and reference to studies of online activism, this article argues for a typology that takes into account web-supported activism, the issues of activist identifications, and the radical democratic ideal of a unity created and sustained by diverse subject positions.

Next, we will lay the groundwork for this typology by recommending that activism be conceived of as participation grounded in the notion of radical democracy and by discussing the formation of unity across diverse political positions through the creation of frontiers. We will then outline different forms of websupported activism by discussing studies of activism in the digital age. Based on these conceptions and discussions, we will identify two axes that form the matrix in which we locate our typology of activism.

\section{Activist participation in radical democracy}

In this article, we depart from an understanding of activism as a form of political participation. It is common to distinguish between narrow and wide definitions of political participation (Bengtsson, 2008: 116). Narrow definitions sometimes include nothing more than casting a vote every four years whereas wide definitions include all kinds of expressions of opinion, from blogging to non-violent civil disobedience as well as more radicalised forms such as property damage. Participation has come to refer to activities with the purpose of influencing society at large (Esaiasson and Westholm, 2006: 15). In line with these discussions, it is possible to define different forms of participation - such as parliamentary, activist, and cultural participation - in which activist participation is understood as political participation external to representative democratic institutions but with an explicit aim to influence public decision-makers (Svensson, 2011). The boundaries between what we label as participation and what we label as activism are thus fluid.

Laclau's (2005: 73-74) splitting of groups into smaller units of demands - as presenting claims and expressing difference to a certain established order - further contributes to our understanding of activism. Understanding activism in terms of demands places emphasis on the importance of difference, so vital to radical democracy. Demands include both social movement types of participation and short-term commitment to single issues. Temporary employments of oppositionality may also be understood as contemporary forms of social movements. As Tilly and Wood (2012) argue, these represent an additional form relative to more sustainable and 
continual involvement in 'political decision-making power' (p. 123). Social movements are thus heterogeneous and fragmented phenomena with diverse forms of action, modes of organisation, and forms of meaning (Melucci, 1996). Represented in online activism, these heterogeneous phenomena appear to be unities following a single aim but are in fact diverse in the forms of action they deploy and the positions they take relative to the contentious Other against which they struggle.

In activist demands today, we see the increasing use and importance of social media platforms like Facebook, Twitter, and YouTube. How do such platforms influence activist participation? There have been many attempts to theorise the role of the internet for activist demands. Social media platforms are claimed to democratise participation, making participation in the form of expression of opinions and political mobilisation more accessible to a wider segment of the population (Jenkins, 2006; Bruns, 2008; Shirky, 2009). Numerous studies have been conducted on how activists use social media platforms to mobilise support and organise themselves and their campaigns (see Bimber et al., 2005; Breindl, 2012 for an overview; Earl and Kimport, 2011). Already in 2002, Rheingold drew attention to new possibilities for the organisation and coordination of protest with the aid of mobile and digital media through his concept of SmartMobs. Today, social media platforms are discussed as affording connective action through immediate, horizontally interactive, and highly personalised communication (Bennett and Segerberg, 2012), with coordination being an important aspect in case studies (Harlow, 2011; Enjolras et al., 2012). It is important to stress that the present article does not seek to analyse the role of social media platforms in activism or to provide details about the different media technologies and platforms that are used as sites of and tools for online activism today. We regard online media practices and offline activities as intertwined in contemporary activist demands since offline practices and sociability work in tandem with their online versions in present-day connected societies (Baym, 2010). Practices and patterns continue to thrive in new media environments and vice versa (Baym and boyd, 2012: 320). We wish to discuss this media environment - with digital media becoming increasingly important for activists - from the perspective of radical democracy.

Inspired by the ideal of radical democracy, our emphasis is not primarily on the affordances of social media platforms for organisation and mobilisation of contemporary activist demands but rather on the affordances they offer activists for exploring their multi-faceted identities (see Papacharissi, 2011). Already in 1995, Turkle (1995) concluded that computers in general - and the internet in particular - redefine how humans negotiate their identities. In order to study contemporary activist demands, we must consider how activists negotiate their identities, present themselves, express difference, and communicate political positions in a digital media 
environment. Indeed, departing from the ideal of radical democracy, we are interested in expressions of difference and conflictual claims to the established order - less what is expressed as how difference and conflict are expressed. We take into account that every identity is indeed relational and consequently exists by affirmation of difference to an Other, which is the essence of how antagonisms arise (Mouffe, 1993: 2). Mouffe argues within the framework of radical democracy that understanding how these frontiers are developed is crucial for providing new impulses within a democracy. Studies that deal with the question of collective identity usually discuss the discursive construction of identity in protest and frames (Jansen, 2000; Bassiouney, 2012; Langman, 2013; Meraz and Papacharissi, 2013). More diverse mobilisations of social movements are discussed as the "personalisation of politics" based on the individual expression of personal action frames that coexist or have even replaced collective action frames (Bennett, 2013). In-depth studies of activist identifications and how difference is expressed in activist demands are, however, surprisingly rare. One of our points of departure thus revolves around how activists view themselves and fellow participants as activists and how they express difference and dissent.

This also creates a counter-argument to the debate concerning whether digital media lead to fragmentation and polarisation of political opinion (see Sunstein, 2002) since the radical democracy perspective grants fragments a relational component, understood as constructions of a 'we' and a 'them' (see Mouffe, 1993). Digital media offer spaces in which different groups can express their identity to gain publicity as well as to which they can retreat and have the chance to prepare and to negotiate their identity (Dahlberg, 2007). Radical democracy thus emphasises the construction of frontiers to an outside Other and the formation of unity across diversity against a common enemy (Mouffe in Carpentier and Cammaerts, 2006). The radical in radical democracy refers to such expressions of difference and includes conflict and dissent as important elements in a democracy. Activist demands may consist of multiple subject positions of groups and individuals that temporarily unite and then disperse again once the outside Other has dispersed. Identifying an outside Other is thus related to constructing a temporarily coherent $U s$, which is important for different individuals and groupings uniting in an activist demand.

Because radical democracy is partly a normative perspective, it also provides a yardstick for evaluating how positions are expressed and how the outside Other is constructed within an activist demand. To determine this yardstick, we must first consider the notion of conflict. Conflict lies at heart of processes of identification since, as mentioned above, the construction of frontiers always entails identification of an Other. Political struggles can be traced back to such moments when a communal We is established in contrast to a Them (Mouffe, 2005). It 
would be futile to seek to reconcile $U s$ and Them in some sort of consensus (Mouffe, 2005). This would overshadow difference and conflict, which goes to the core of the political, which Laclau and Mouffe (1985) describe with 'democratic pluralism' as a main component. Politics is about bringing differences to the fore, but this entails respecting the Other as an adversary and not as an enemy to be eliminated. By outlining the concept of agonism, in contrast to antagonism, Mouffe (2005) suggests a conception of the Other as an adversary to be acknowledged, which is important for displaying the heterogeneity of conflictual forces constituting the political. Thus, in conclusion, radical democracy offers guidance on how to study activist identifications (as constructed around frontiers separating $U s$ from Them), how to evaluate such identifications (if they are revolving around expressing dissent and difference to the established order), how to create a normative yardstick (by analysing whether the Other is conceived of as an enemy or as an adversary), and how to accept democratic pluralism as an ideal form of democracy.

We argue that, for a typology of activism in the digital age, the notion of antagonism and agonism within radical democracy plays an important role in developing a collective identity in activist participation. Consequently, we derive the first axis of our typology from the ideal of radical democracy based on this notion. The construction of frontiers between $U s$ and Them is thus part of the identification process in activism through media technology and can take different forms, including not only friend-enemy constellations but also the ideal of the adversary whose idea is criticised but who is nevertheless respected as part of democratic pluralism.

\section{From Clicktivism and Hacktivism to Activist Participation}

Online actions are inseparable from economic and political struggle. In his critical theory of technology, Feenberg (2002) argues for a focus on human agency that is situated between structure and constructivism. From this perspective, technology reinforces hierarchies and power relations that are part of the prevailing political system. However, technological invention also provides new possibilities for subversive actors who can use the technological potentialities to challenge the system by appropriating new media technology for their causes. Feenberg (2002) explains these different implications of technology though the 'principle of the conversation of hierarchy' and the 'principle of democratic rationalization' (p. 92). The first of these describes the social hierarchy that is reproduced when new media technologies are introduced. Surveillance and control sustain the societal structure. The second describes how technology is used to undermine existing hierarchies and control. This potential of technologies is not always realised and is partially dependent on the space in which the dominated are free to act. This underlines the necessity of including the means and forms that economic and political struggle take, which we will discuss by referring to studies on different forms activist participation in 
the digital age and in particular the role of civil disobedience directed against domination.

Studies about online activism seldom differentiate between the forms of participation, yet a diversity of forms exist, dependent on the actors' political positions and the means they are prepared to use. The less radical forms of participation are related to citizen engagement revolving around identity expressions. Concepts that describe how such participation is embedded into everyday life of citizens are subactivism (Bakardjieva, 2009), mundane citizenship (Bakardjieva, 2012), or the concept of civic culture (Dahlgren, 2006, 2009), including activist participation in the digital age within the broader category of citizenship and engagement. These studies highlight the relevance of such forms of participation, including comments in discussion forums, likes and comments on Facebook, the signing of online petitions, and shows of solidarity with a demand on Twitter as well as the spreading of awareness (and perhaps mobilisation of participation) by sharing and disseminating information, for example through retweets, Facebook status updates, blog posts, or other forms of information sharing or updating. Such forms of participation are important for the visibility and acknowledgement of activist demands and thus also important for displaying difference and conflict.

However, these forms of participation - although part of the broader repertoire of the political - differ from acts of civil disobedience. Due to their simplicity and lack of risk exposure, these forms of activist participation are sometimes referred to as lazy with notions such as slacktivism (Morozov, 2011), clicktivism (White, 2010), or networks without a cause (Lovink, 2011). These notions do not necessarily claim that technology has no influence on our lives. Morozov (2013) argues, however, that in order to understand their impact, we must stop thinking of internet technologies as inherently revolutionary. Nonetheless, such actions may turn into civil disobedience and expose activists to a high level of risk when carried out in, for example, authoritarian states in which the mere act of publicly voicing criticism may be considered an act of civil disobedience. A recent example is the arrest of a Chinese blogger who posted a joke on Twitter about the Communist leadership (The Guardian, 2012). As a result, it is not necessarily the forms of actions alone that determine the type of activist and whether he or she is inclined to civil disobedience: Context matters as well. In other words, a situational and relational component determines activists' readiness to expose themselves to risk of surveillance and punishment by potentially hostile authorities.

Many forms of activist participation revolve around protest in the streets, a specific event or a temporary spontaneous resistance. These can range from anti-fascist protests (Neumayer, 2013), spontaneous formations of 
lecture hall occupations by university students (Maireder and Schwarzenegger, 2012), local events such as protest formation to protect a community owned bath-house (Svensson 2012), protests organised around global events such as a climate conference in Copenhagen (Askanius and Gustafsson, 2010), and small protest formations against local actions of authoritarian governments in China (Jun, 2013). Just as with offline participation, online forms of resistance vary and may indeed include mass action and civil disobedience as well as symbolic action, performance acts, and artistic expression of resistance. In such events, social media alongside the mobile phone (not always easily distinguishable) are used for expressing activist identity, coordinating, connecting individuals, mobilising online and offline protest as well as traditional political actions such as signing petitions, and reporting on events on-site or showing solidarity from a distance (Rheingold, 2002; Earl and Kimport, 2011; Neumayer and Stald, 2014). In an overview of alternative and activist new media, Lievrouw (2011) discusses culture jamming, artistic expression, hacking, participatory journalism (such as IndyMedia), mediated mobilisation, and coordination of physical protest as forms of political action related to new media.

In media studies, activists are understood as using media in general, and online media in particular, to express their political demands in their struggles, communicate alternative perspectives, organise, challenge dominant discourse, and coordinate protests (Askanius and Gustafsson, 2010; Dunbar-Hester, 2009; Lester and Hutchins, 2009; Mattoni, 2012; Mercea, 2011; Postmes and Brunsting, 2002; Rucht, 2004). A major concern in these studies is the relationship between the social web and mainstream mass media. Producing visibility for a demand in the mainstream mass media, strategies range from mass demonstrations, property destruction, to public performance and civil disobedience (Cammaerts, 2012: 121). In particular, mass action requires (mostly) temporary activist formations uniting different participants using symbolic forms of resistance as well as more radical forms to produce visibility (Neumayer, 2013). However, many participants - on social media platforms as well as in the streets - would not necessarily consider themselves to be activists. For example, individuals outside Iran sharing pictures and information about the post-election protests against President Ahmandinejad in 2010 may feel that they are acting politically and are supporters of the demand, wishing to show solidarity with Iranian street protesters and make their demand visible, but they would rather consider their engagement as a form of political support than as activism per se. Furthermore, the identification with an activist demand by a heterogeneous mass of supporters through likes on Facebook or other forms of showing solidarity does not necessarily mean identification with radical activists and participation such as civil disobedience. Although these participants often do not consider themselves to be activists, they do show a level of engagement that plays an important role in the formation of alliances against a common Other (Svensson et al.) and thus display the 
heterogeneity of the political.

Apart from temporary formations largely based on offline action but where social media platforms play an important role, certain protests have become symbols of digital culture and online resistance. These include the Occupy movement, which started in New York and travelled across the world. The Occupy movement not only used social media platforms but also based its formation on flat hierarchies, loosely connected individuals without a clear leadership, self-organisation, and creation from the grassroots (Gitlin, 2012; Juris, 2012; Langman, 2013; Penney and Dadas, 2013). Although the Occupy movement was accompanied by some violent action, most of the activists - even the more radical ones - would not use violence to pursue their goals (Gitlin, 2012). Despite only using non-violent action, radical activists were exposed to a high level of risk (since they engaged in civil disobedience) and relied on online communication through secure connections that could not be traced back by the police. The non-violent image also produced visibility, solidarity, and a positive portrayal of the movement, especially on social media platforms. Many went online to show their solidarity as well as their disapproval of police violence against the activists in the streets as portrayed in the mainstream media (Juris, 2012: 261).

The global solidarity shown for a political demand through social media platforms becomes even clearer in the uprisings against oppressive governments in Myanmar (Stirland, 2007), Iran (Morozov, 2009), and Egypt (Smith, 2011). Despite the fact that, in these countries, many participants in offline protest events did not have access to online media platforms and would also have faced surveillance by authorities, arrest, torture, and punishment for publicly communicating their disapproval of the government, the global solidarity with the protesters shown through social media platforms was important in strengthening the movements. For example, camera phone footage of activists suffering in protest events uploaded on social media platforms evoked solidarity with activists in Iran, Myanmar, and Egypt (Andén-Papadopoulos, 2013). At the same time, such footage also exposed the activists to a high level of risk. Thus, while social media may play an important role in creating visibility, this visibility could also become subject to surveillance by hostile authorities (Penney and Dadas, 2013). In a study on online communication in protest events, Mercea (2011) concludes that digital participation is more extensive when participants are exposed to a low level of risk. Awareness of being under surveillance by authorities decreases readiness to use public platforms to organise and carry out political action. 
There are also structural constraints that contemporary activist demands face in using market-based social media platforms (Cammaerts, 2012: 128). Examples include the closing down of accounts that represent more radical forms of activism, such as Twitter closing down the online activist groups' Anonymous account called \#Anon_Operation. Again, the role of social media for mobilisation across a broad political spectrum is important, but these platforms have structural disadvantages for more radical activists relying on secure communication. When acting in civil disobedience, the structural hindrances of the technology are thus most obvious as the data is owned by a dominant economic player, i.e. the owner of a media platform such as Facebook, and can potentially expose activists to a high level of risk through sharing this data with authorities such as governments (in particular, oppressive governments) or police.

With the exception of Anonymous, street action played an important role together with social media platforms in the forms of activism mentioned so far. But there are also forms of resistance that only occur online such as hacking, the leaking of information, and crowdsourced online attacks. LulzSec and Anonymous are examples of loosely connected groups of individuals clearly identifying as activists who have a clear political agenda despite claiming to do things for the lulz (Coleman, 2013). At the same time, many individuals who would not consider themselves to be activists showed support for the actions of these groups through likes, comments, and even participation in actions that require a mass of people's crowdsourced online action. Mobilising a large number of people to spam an e-mail account or shut down a website by mass action does not necessarily make everyone sending an e-mail or using the functionalities of the website an activist. Similarly, hackers cannot automatically be labelled as 'hacktivists' since not all of them would identify with that term (see Taylor, 2005 for a discussion of hackers and hacktivists). As Coleman (2013) argues, apart from a political message, hacking also includes an artistic component. This again shows how closely different forms of online activist participation work together and how blurred the boundaries between them can be. At the same time, they often fall under the same terminology. Anonymous and WikiLeaks, for example, use very different forms of participation to create visibility and resistance, but although their actions differ, they often fall into the same category of online activism (Coleman, 2011). The differences between forms of participation and identity formations thus vary considerably across activist demands as well as between the individuals who are part of these demands and the different actions they are willing to undertake for the demands. From these differences in activist participation, we derive the second axis of our typology as readiness to act in civil disobedience. In the following, we outline how this typology can assist in understanding acts of online resistance and oppositionality as acts of identity, performance, and acceptance of difference, with the addition of a relational perspective. 


\section{Towards a Typology of Activists}

We especially find that readiness to act in civil disobedience is a key dividing line in how difference and dissent are expressed. In developing a typology of activists, we thus seek to acknowledge the difference between expressing political opinion on social media platforms as part of an act of identity expression and selfrepresentation and to preparedness to act in civil disobedience and expose oneself to a high level of risk (for instance, legal punishment). Along these lines, some participants do not consider themselves to be activists but instead regard themselves as citizens who are politically engaged in a general sense. Readiness to engage in civil disobedience is thus connected to the self-conception of activists in contrast with participants who conceive of themselves as merely politically interested individuals. Individuals could, for example, participate by donating money, tweeting, retweeting, posting, and commenting on Facebook and YouTube. Readiness to engage in civil disobedience forms the first axis of our typology, an axis that to a large extent runs from expressing difference and dissent on online social media platforms to expressing difference and dissent through acts of civil disobedience and property damage.

The second axis concerns conflict and contestation as discussed in radical democracy. The axis revolves around whether the Other is conceived of as an enemy (antagonism) or an adversary (agonism) and how participants identify in relation to the Other. It thus deals with the relational perspective of identity in situations of conflict and contestation. There are different examples of when the Other is portrayed as enemy or an adversary in activist demands. In many activist demands, participants want to be heard and listened to, but when this fails, elected representatives are often portrayed as an enemy (Svensson et al.). On the other side, in activist demands we also find participants involved in party-politics and civil society groups (see Svensson, 2012; Heissenberger, 2010), prepared to listen to the Other as an adversary. Different ways of conceiving the common Other coexists within activist demands where radical activist collectives demonstrate or organise online mass action together with civil society groups temporarily connected to the demand (Neumayer, 2013). They differ, however, in how they perceive the Other.

Whether the constructions of frontiers between $U s$ and the outside Other could be regarded as agonism or antagonism in Mouffe's understanding depends on the context, the process of contestation, and the political positions proposed. To move from mere hostility to the Other to respecting that the Other has a different opinion would, in our axis, mean what Mouffe normatively labels as agonism. The Other is regarded as an adversary 
rather than an enemy that needs to be eliminated. Demands for real democracy phrased within a participatory democratic discourse to be heard and consulted by elected representatives before decision-making suggest such an adversarial approach vis-à-vis the Other. The aim is for the display of difference by including radical positions. Therefore, in outlining an ideal activist type from the perspective of radical democracy, we cannot merely attend to how the Other is conceived but also whether it is done in a discourse favouring the display of heterogeneity in the political.

\section{Outlining the Contours of Activist Types}

Along the two axes ([1] readiness to engage in civil disobedience and [2] the relationship to the Other as antagonism and agonism), we propose a four-field that allows us to identify four activist types. These four types are based on the notion of activist participation and identity (i.e. identification of activists in relationship to the Other) and readiness to act in civil disobedience as a criterion that does not dismiss less radical forms of political engagement but allows for a differentiation and heterogeneity of opinions and positions. Along the two axes, we identified the following types of activists: The salon activist, the contentious activist, the law-abiding activist and the Gandhian activist.

Figure 1 about here

The salon activist identifies the Other as an enemy who should be fought against rather than accepted. The relationship to the Other can be described as antagonistic. This type of activist is prepared to engage politically within the legal framework but is not prepared to engage in civil disobedience and be exposed to a high level of risk as a result of political actions. The salon activist most likely identifies as politically active but not necessarily as an activist. Although this type might support activists and their causes and perhaps form a temporary unity with them against the common enemy, fear of punishment would prevent them from engaging in more radical actions. Despite openly articulating hostility and disapproval of the enemy through antagonistic political positioning, the salon activist mostly stays within the bounds of legality. This type of activist might join an officially registered demonstration, join a Facebook group, and tweet and discuss online but would not engage in any illegal actions such as property damage, illegal blockades and demonstrations or support of civil disobedience online. In anti-fascist protests, civil society engages in symbolic actions such as likes, tweets, clicks, and comments online as well as symbolic actions such as registered music events or sit-ins to support the 
vague demand 'against the neo-Nazis'. Although civil society in these actions clearly considers the neo-Nazis to be an enemy, acts politically, and feels politically engaged, they would not consider themselves to be activists per se and would not engage in or agree with the actions of radical anti-fascist groups (Neumayer, 2013).

This type of activist is made more visible today with the use of social media platforms. Outlining the contours of the salon activist thus resonates in discussions of internet-based activism and with the somewhat derogatory labels of armchair activists and slacktivists. While easy to dismiss as non-important and reduce the form of participation emanating from salon activists to simply identity expression, this form participation is important for showing, spreading and making visible a demand - put it on the agenda - as well as generating support and recognition for more contentious types of activists and participation. From a radical democratic perspective, this type of activism thus affords participants the ability to explore and express their multi-faceted identities by identifying a common outside Other, temporarily uniting different participants in an activist demand and thus contributing to the display of difference. However, the antagonistic - rather than adversarial - relationship to the enemy makes the saloon activist less ideal for radical democracy since this implies the elimination of visibility of demands that oppose the activists' own.

The contentious activist is prepared to engage in civil disobedience to achieve change. This type of activist is mostly aware of the risk involved in civil disobedience and is prepared to face legal prosecution. The contentious activist does not consider the Other as an adversary, i.e. someone who must be listened to, but as a nonacceptable enemy. The contentious activist most likely identifies as an activist. Acting in civil disobedience is used strategically to radicalise political positions and the political identity of the contentious activist. The contentious activist would most likely be part of a militant activist collective. The contentious activist participates in actions such as illegal occupations or property damage (see for example, Svensson et al.) as well as civil disobedience online by hacking websites, eliminating content, sending threats to the enemy through digital media, and illegal action in general. Civil disobedience is considered a necessary strategy for resisting an outside Other that cannot be tolerated and has to be eliminated. The risk of punishment is part of the struggle. This underlines the ambiguous status of the activist type from the perspective of radical democracy. As with the saloon activists, constructing the Other as an enemy rather than an adversary makes the contentious activist less ideal for radical democracy. If, however, the Other does not accept the agonistic rules of game by accepting a common political ground on which differences are allowed to be played out, its antagonistic relationship cannot be overcome or turned into agonism. An antagonistic relationship can also be historically grounded and be part of the political identity of activist groups, such as anti-fascists in relation to fascists (see Neumayer, 2013), 
Islamists in relation to anti-Islamists and, on a more abstract level, anarchists in relation to state control. Should such an Other be allowed to enter the political arena or be combatted in these cases of unsolved antagonisms?

Perhaps the biggest problem for this activist type is the inclination towards engagement in violent action. Civil disobedience need not imply violent action per se, though it seems that the combination of positioning the Other as an enemy together with the readiness to engage in civil disobedience with possible punishment as part of the struggle make violent action a more likely outcome. From a radical democratic perspective (seeking political common ground on which differences are allowed to be played out among adversaries) violence is not preferred. At the same time, antagonisms such as anti-fascists opposed to neo-Nazis are clearly elements of contemporary democracy.

The law-abiding activist is located on the opposite corner of the four-field. This activist type respects the Other as an adversary who should be listened to and whose opinion has to be valued in discussion even though it is contrary to one's own political position. The law-abiding activist has a strong political opinion, has a clear political position, and engages in political participation. However, the law-abiding activist is not prepared to engage in civil disobedience and is not always likely to identify as an activist. Instead, this activist type engages in a participatory democratic discourse, which in itself signals a greater willingness to conceive of the Other as an adversary to discuss with. Examples of law-abiding activists can be found in mainstream civil society groups when acting against neo-Nazis (see Neumayer, 2013) and citizens who engage in a struggle for the local community together with more contentious types of activists (see Svensson, 2012).

As with the saloon activist, social media platforms offer many opportunities for law-abiding activists to explore, express, and negotiate their identities by participating in campaigns, petitions, and rallies. They can thus temporarily unite with different activist types against a common outside Other, thereby contributing to broadening political participation and visibility of activist demands. It is, however, clear that by staying within the boundaries of the law, being more inclined towards discussion, and making use of a general participatory discourse (informed by ideas of deliberation and agreement), the law-abiding activist does not accept civil disobedience as a form of political participation. It is true that constructing the Other as an adversary rather than an enemy makes the law-abiding activist more ideal for radical democracy. However, positioning of the other as an adversary and lack of readiness to engage in civil disobedience make this activist type more inclined towards discussion, consensus building, and the seeking of agreements, which could potentially push difference and conflicts into the background and hide power structures. As Morozov (2009) argues, oppressive regimes can 
strategically use social media to give the public a forum to discuss and criticise the government. This can support the hierarchy and existing power structures as space is set aside for apparently democratic debate, yet this space is visible to and controlled by the government, which strengthens its power by manipulating the discussions (as Feenberg's principle of the conversation of hierarchy also underlines). These processes are not acceptable from a radical democratic perspective.

The Gandhian activist is situated in the fourth quadrant of the four-field. Inspired by the example of Mahatma Gandhi, we envision this kind of activist as characterised by a readiness to act in civil disobedience in order to achieve change, while at the same time accepting the Other as an adversary, that is, someone having the right to exist and to express a political opinion that should be respected. This indicates a high level of readiness to act in civil disobedience and risk punishment to struggle for social change but also accepting a pluralism of opinions. It is, however, important to keep in mind that Gandhi's civil disobedience was always non-violent as it tends to regard the Other as an adversary rather than as an enemy. The agonistic relationship to the Other makes it less likely for the Gandhian activist to engage in violent action.

The Gandhian activist is an ideal activist type, the yardstick against which activist participation should be measured if regarding difference, conflict, and pluralism as important criteria of democracy. This activist type regards the Other as an opponent to be considered, one who has the right to exist despite the conflicting relationship. The Gandhian activist does not seek consensus, is prepared to engage in conflictual struggle, and broadens activist participation by radical positioning. This being the ideal radical democracy activist type, it is rare to find. However, this activist type, loosely outlined here, provides a good yardstick for measuring how activist participation in digital media can lead to social change. On the one hand, social media platforms could provide fertile ground for such participation, a political arena in which disagreement and conflict can be played out in a non-violent yet radical manner. On the other hand, the market-based ideals of social media platforms can create structural disadvantages for this activist type and lead to the exclusion of radical political opinions when they are not attached to violent actions such as damages. A content analysis of media coverage of the 2010 U.K. student protests shows that, to produce visibility for a cause, the logic of damage is one of the most important resorts of activists for stimulating public debate (Cammaerts, 2013). Consequently, the Ghandian activist might be overheard in the saturated online media environment when only engaging in non-violent civil disobedience. Furthermore, user accounts being shut down for expressing a political opinion is counterproductive to radical democracy. In 2011, activists claimed that several Facebook pages related to the U.K. student protests were shut down by the company (Malik, 2011). Outlining this ideal activist type thus also makes us aware of online 
media's structural hindrances for expressing radical political opinion.

\section{Concluding Remarks}

The political position of an activist demand and the societal context in which it operates are important elements to be considered. One's own political position also influences, for example, readiness to engage in civil disobedience, meaning that the same individual participants can adopt different forms of activist participation in different protest events depending on political cause. The four activist types outlined here are thus neither static nor fixed and may differ depending on the political demand for which activists are fighting. There is also an array of different subtypes of activists to be delineated and defined within each quadrant. In the field of contentious activism, for example, one finds more ritual types of activists, in which the contentious actions themselves, rather than outcomes, are the most important part of their engagement (sometimes labelled as 'looters').

There are certainly other dimensions and categories to consider for a typology of contemporary political activism. This typology does not, however, aim to offer a full account of all different types of activists today but rather to evaluate and discuss activist participation from the perspective of radical democracy. This implies that antagonism can be turned into agonism, and different political opinions can be accepted and respected in democratic pluralism. It also seeks to inform and question the contemporary derogatory categories of slacktivism, feel-good activism, etc. by adding the component of activists' identifications and readiness to act in civil disobedience.

The typology reflects the contingency of activism today. The different activist types represent political positions as part of identity negotiations reflected in forms of action used to produce visibility for a cause in these mediated environments. They often supplement each other and work together in contemporary activist demands in which social media play an important role. The types we identified thus appear in combination with one another, embedded in a set of power relations that activists seek to challenge as well as in political and cultural environments that frame their appearance. They are an expression of the contingency of activist participation in contemporary media environments, embedded in constraints and the potential of the political and cultural environments in which they act. This typology of activists stresses the generative form of contemporary activism as the different forms can appear in relationship with each other, and activists can take on different roles, depending on their respective political causes and involvement in the actions. 
Finally, outlining activist types based on the ideal of radical democracy also highlights the problem of social media platforms being based on market principles. If owners of these platforms shut down radical voices, it is counterproductive to radical democracy. Consequently, the normative component for describing an ideal activist type also makes visible the structural hindrances for the ideal of democratic pluralism in the digital age.

\section{References}

Andén-Papadopoulos, K. 2013. Citizen camera-witnessing: Embodied political dissent in the age of 'mediated mass self-communication'. New Media \& Society, published online before print, doi: 10.1177/1461444813489863.

Askanius, T. and Gustafsson, N. 2010. Mainstreaming the Alternative: The Changing Media Practices of Protest Movements. Interface 2 (2): 23-41.

Bakardjieva, M. 2009. Subactivism: Lifeworld and Politics in the Age of the Internet. The Information Society 25(2): $91-104$.

Bakardjieva, M. 2012. Mundane Citizenship: New Media and Civil Society in Bulgaria. Europe-Asia Studies 64 (8): $1356-1374$.

Bauman, Z. 2001. The Individualized Society. Cambridge: Polity Press.

Baym, N. K. 2010. Personal Connections in the Digital Age. Cambridge: Polity Press.

Baym, N. K. and boyd, d. 2012. Socially Mediated Publicness: An Introduction. Journal of Broadcasting \& Electronic Media 56 (3): 320-329.

Bengtsson, Å. 2008. Politiskt deltagande. Lund: Studentlitteratur.

Bennett, W. L. 2013. The Personalization of Politics: Political Identity, Social Media, and Changing Patterns of Participation. The Annals of the American Academy of Political and Social Science 644 (1): 20-39.

Bennett, W. L. and Amoshaun, T. 2009 Identity, technology, and narratives. Transnational activism and social networks. In Routledge Handbook of Internet Politics, edited by A. Chadwick and P.N. Howard, 146-260. London: Routledge.

Bennett, L. W. and Segerberg, A. 2012. The Logic of Connective Action. Information, Communication and Society 15(5): 739-768.

Bimber, B., Flanagin, A. J. and Stohl, C. 2005. Reconceptualizing Collective Action in the Contemporary Media Environment. Communication Theory 15 (4): 365-388.

Breindl, Y. 2012. The Dynamics of Participation and Organization in European Digital Rights Campaigning. JeDEM - eJournal of eDemocrcay and Open Government 4 (1): 24-44.

Bruns, A. 2008. Blogs, Wikipedia, Second Life, and Beyond. From Production to Produsage. New York: Peter Lang. 
Carpentier, N. and Cammaerts, B. 2006. Hegemony, Democracy, Agonism and Journalism. Interview with Chantal Mouffe. Journalism Studies 7 (6): 964-975.

Cammaerts, B. 2012. Protest logics and the mediation opportunity structure. European Journal of Communication 27 (2): 117-134.

Cammaerts, B. 2013. The Mediation of Insurrectionary Symbolic Damage: The 2010 U.K. Student Protests. The International Journal of Press/Politics, online before print, doi 10.1177/1940161213496283.

Coleman, E. G. 2011. Hacker Politics and Publics. Public Culture 23 (3 65): 511-516.

Coleman, E. G. 2013. Coding freedom: The ethics and aesthetics of hacking. Princeton: Princeton University Press.

Dahlberg, L. 2007. Rethinking the fragmentation of the cyberpublic: from consensus to contestation. New Media and Society 9 (5): $827-847$.

Dahlgren, P. 2006. Doing citizenship: The cultural origins of civic agency in the public sphere. European Journal of Cultural Studies 9 (3): 267-286.

Dahlgren, P. 2009. Media and Political Engagement. Citizens, Communication and Democracy. Cambridge: Cambridge University Press.

Dunbar-Hester, C. 2009. 'Free the Spectrum!' Activist Encounters with Old and New Media Technology. New Media \& Society 11 (1-2): 221-240.

Earl, J. and Kimport, K. 2011. Digitally Enabled Social Change. Activism in the Internet Age. Cambridge, MA: MIT Press.

Enjolras, B., Steen-Johnsen, K. and Wollebæk, D. 2012. Social media and mobilization to offline demonstrations: Transcending participatory divides? New Media \& Society, online before print (November 26).

Esaiasson, P. and Westholm, A. 2006. Deltagandets mekanismer: det politiska engagemangets orsaker och konsekvenser. Malmö: Liber.

Feenberg, A. 2002. Transforming Technology: A Critical Theory Revisited. New York, N.Y.: Oxford University Press.

Gitlin, T. 2012. Occupy nation: The roots, the spirit, and the promise of Occupy Wall Street (1st ed.). New York: itbooks.

Habermas, J. 1990. Strukturwandel der Öffentlichkeit. Untersuchungen zu einer Kategorie der bürgerlichen Gesellschaft [The structural transformation of the public sphere]. Frankfurt am Main: Suhrkamp (original work published 1962).

Harlow, S. 2011. Social media and social movements: Facebook and an online Guatemalan justice movement that moved offline. New Media \& Society 14 (2): 225-243.

Heissenberger, S. 2010. Besetzung, Ritual und Raum. In S. Heissenberger, V. Mark, S. Schramm, P. Sniesko, and R. 
S. Süss (Eds.), Uni brennt. Grundsätzliches - Kritisches - Atmosphärisches (pp. 222-233). Wien: Turia+Kant. Jansen, S. 2000. Victims, Underdogs and Rebels: Discursive Practices of Resistance in Serbian Protest. Critique of Antropology 20 (4): 393-419.

Jenkins, H. 2006. Convergence Culture. Where Old and New Media Collide. New York: New York University Press.

Jun, L. 2013. Mobilized by Mobile Media. How Chinese People use mobile phones to change politics and democracy (PhD thesis). Copenhagen: University of Copenhagen.

Juris, J.S. 2012. Reflections on \#Occupy Everywhere: Social media, public space and emerging logics of aggregation. American Ethnologist 39 (2): 259-279.

Laclau, E. 2005. On Populist Reason. London: Verso.

Laclau, E. and Mouffe, C. 1985. Hegemony and Socialist Struggle. 2001 edition. New York: Verso.

Langman, L. 2013. Occupy: A new social movement. Current Sociology, online before print (17 April).

Lester, L., and Hutchins, B. 2009. Power Games: Environmental Protest, News Media and the Internet. Media, Culture \& Society 31 (4): 579-595.

Lievrouw, L. 2011. Alternative and Activist New Media. Cambridge: Polity.

Lovink, G. 2011. Networks without a cause: a critique of social media. Cambridge, UK: Polity.

Maireder, A. and Schwarzenegger, C. 2012. A Movement of Connected Individuals. Information, Communication \& Society 15 (2): 171-195.

Malik, S. 2001. Activists claim purge of Facebook pages. The Guardian, 29 April, retrieved 24 April 2014 from http://www.theguardian.com/uk/2011/apr/29/facebook-activist-pages-purged

Mattoni, A. 2012. Media Practices and Protest Politics: How Precarious Workers Mobilise. Farnham, Surrey; Burlington, VT: Ashgate.

Melucci, A. 1996. Challenging Codes: Collective action in the information age. Cambridge: Cambridge University Press.

Meraz, S. and Papacharissi, Z. 2013. Networked Gatekeeping and Networked Framing on \#Egypt. Press/Politics, online before print (27 January).

Mercea, D. 2011. Digital Prefigurative Participation: The Entwinement of Online Communication and Offline Participation in Protest Events. New Media \& Society 14 (1): 153-169.

Morozov, E. 2009. Iran Elections: A Twitter Revolution? The Washington Post. Retrieved from http://www.washingtonpost.com

Morozov, E. 2011. The Net Delusion: How Not to Liberate the World. New York: Public Affairs.

Morozov, E. 2013. To Save Everything, Click Here: Technology, solutionism, and the urge to fix problems that don't 
exist. London: Allen Lane.

Mouffe, C. 1993. The Return of the Political. 2005 edition. London: Verso.

Mouffe, C. 2005. On the Political. London: Routledge.

Neumayer, C. 2013. When neo-Nazis march and anti-fascists demonstrate: Protean counterpublics in the digital age

(Doctoral thesis). IT University of Copenhagen, Denmark.

Neumayer, C. and Stald, G. 2014. The mobile phone in street protest: Texting, tweeting, tracking, and tracing.

Mobile Media \& Communication 2(2): 117-133.

Papacharissi, Z. 2011. A Networked Self. Identity, Community, and Culture on Social Network Sites. London:

Routledge.

Penney, J. and Dadas, C. 2013. (Re)Tweeting in the service of protest: Digital composition and circulation in the

Occupy Wall Street movement. New Media \& Society, online before print (15 March).

Postmes, T., and Brunsting, S. 2002. Collective Action in the Age of the Internet: Mass Communication and Online Mobilization. Social Science Computer Review 20 (3): 290-301.

Bassiouney, R. 2012. Politicizing identity: Code choice and stance-taking during the Egyptian revolution. Discourse and Society 23 (2): 107-126.

Rheingold, H. 2002. Smart Mobs. The Next Social Revolution. Transforming Cultures and Communities in the Age of Instant Access. Cambridge: Basic Books.

Rucht, D. 2004. The Quadruple 'A': Media Strategies of Protest Movements Since the 1960s. In Cyberprotest. New Media, Citizens and Social Movements, edited by W. van de Donk, B. D. Loader, and D. Rucht. London, New York: Routledge, 29-56.

Shirky, C. 2009. Here Comes Everybody. How Change Happen when People Come Together. London: Penguin Books Ltd.

Smith, C. 2011. Egypt's Facebook Revolution: Wael Ghonim Thanks The Social Network. The Huffington Post. Retrieved 22 September 2012, from http://www.huffingtonpost.com/2011/02/11/egypt-facebook-revolution-waelghonim_n_822078.html

Stirland, S.L. 2007. 'Open-Source Politics' Taps Facebook for Myanmar Protests. Wired online. Retrieved May 29 2008 from http://www.wired.com/politics/onlinerights/news/2007/10/myanmarfacebook

Sunstein, C. R. 2002. Republic.com. Princeton: Princeton University Press.

Svensson, J. 2011. Theorizing Citizenships in Late Modern ICT Societies. Triple C. 9 (2): 277-288.

http://www.triple-c.at/index.php/tripleC/article/viewArticle/195

Svensson, J. 2012. Social Media and the Disciplining of Visibility. Activist Participation and Relations of Power in Network Societies. European Journal of E-Practice. June/July 2012 (16): 16-28. 
Svensson, J., C. Neumayer, A. Banfield-Mumb and Schoßböck, J. 2015. Identity Negotiation in Activist

Participation Online. Communication, Culture \& Critique 8(2), forthcoming.

Taylor, P.A. 2005. From hackers to hacktivists: speed bumps on the global superhighway? New Media and Society 7(5): $625-646$.

The Guardian 2012. China arrests blogger for Twitter joke (21 November). Retrieved 15 July 2013 from http://www.guardian.co.uk/world/2012/nov/21/china-arrest-blogger-twitter-joke

Tilly, C. and Wood, L. J. 2012. Social movements, 1768-2012 (3rd ed.). Boulder, CO: Paradigm Publishers.

Turkle, S. 1995. Life on Screen. New York: Simon \& Schuster.

White, M. 2010. Clicktivism is ruining leftist activism. The Guardian. Retrieved 15 July from

http:/www.guardian.co.uk/commentisfree/2010/aug/12/clicktivism-ruining-leftist-activism

\section{Biographies}

Christina Neumayer is an assistant professor at the IT University of Copenhagen with an interest in digital media, radical politics, activism, social movements, and civic engagement. She received her PhD from the IT University of Copenhagen in 2013.

Jakob Svensson is an associate professor at Uppsala University with an interest in new media and participation, and mobile communication for development. He received his PhD from Lund University in 2008 and has previously worked at Karlstad University. 